ScIDice

\section{Effect Of Calcium Supplementation As An Adjunct To Scaling And Root Planing In The Treatment Of Chronic Periodontitis}

Research Article

Allour Vaishnavi ${ }^{1}$, Arvina Rajasekar ${ }^{2 *}$

${ }^{1}$ Saveetha Dental College and Hospitals, Saveetha Institute of Medical and Technical Sciences (SIMATS), Saveetha University, Chennai- 77, India.

${ }^{2}$ Senior Lecturer, Department of Periodontics, Saveetha Dental College and Hospitals, Saveetha Institute of Medical and Technical Sciences [SIMATS],

Saveetha University, Chennai- 77, India.

\title{
Abstract
}

Background: Periodontal diseases are one of the most common diseases in the oral cavity. It has long been recognized that patients in periodontal maintenance programs taking calcium supplementation had better periodontal health compared to patients not taking supplementation.

Aim: To evaluate the effect of calcium supplementation as an adjunct to scaling and root planing in the treatment of chronic periodontitis.

Materials and Methods: The study was performed as a randomised controlled trial. A total of 22 patients were selected randomly, comprising two groups, 11 in each, with generalised chronic periodontitis. Both the groups underwent scaling and root planing. The first group was asked to take a placebo and the second group was advised calcium supplements for 3 weeks. The pocket depth and gingival index scores were calculated after scaling and root planing (baseline). Then subsequently after 3 weeks, the pocket depth and gingival index were re assessed. Data was analyzed using SPSS software, Version 23. Unpaired $\mathrm{t}$-test was done to compare the difference in pocket depth and gingival index between the two groups.

Results: The group 1 was found to have a mean gingival index value of $2.89 \pm 0.02$ at baseline and $2.20 \pm 0.01$ after 3 weeks. The gingival index was measured to be $2.92 \pm 0.03$ at baseline in group 2 and post 3 weeks the gingival index value reported to be $1.50 \pm 0.03$. The difference in gingival index scores between both the groups was found to be statistically significant $(\mathrm{p}=0.002)$. The mean pocket depth of the individuals who underwent only scaling and root planing were found to have a score of $5 \pm 0.05$ at baseline and $3 \pm 0.01$ post 3 weeks. In group 2 the pocket depth was measured to be $4 \pm 0.02$ at baseline and $2 \pm 0.03$ post 3 weeks. The difference in pocket depth between both the groups was statistically significant, $(p=0.000)$.

Conclusion: The present study reveals that the calcium supplementation given as an adjunct to scaling and root planing was more effective compared to scaling and root planing alone in the management of chronic periodontitis.

Keywords: Calcium; Chronic Periodontitis; Pocket Depth; Scaling and Root Planing; Innovative Technique.

\section{Introduction}

Periodontitis is an inflammatory disease of the supporting tissues of the teeth caused by a group of specific microorganisms. If it is left untreated, it leads to the destruction of both soft tissues and hard tissues resulting in increased pocket depth, clinical attachment loss, recession, mobility, bone loss, pathologic migration of the teeth and tooth loss [1-7]. It is a multifactorial disease. Even though plaque is the primary etiology, the disease is aggravated by a variety of risk factors including age, systemic diseases, gender, genetic factors, smoking, stress, hormones[8-11].

Periodontitis is one of the most common diseases in the oral cavity. In the management of periodontitis, scaling and root planing is one of the most effective methods. To help in faster healing of the periodontitis many adjuncts such as herbal agents, therapeutic agents like tetracycline, minocycline and other antibiotics. These adjuncts aid in the destruction of microorganisms and help in speedy recovery of periodontium to its normal state [3, 12-16].

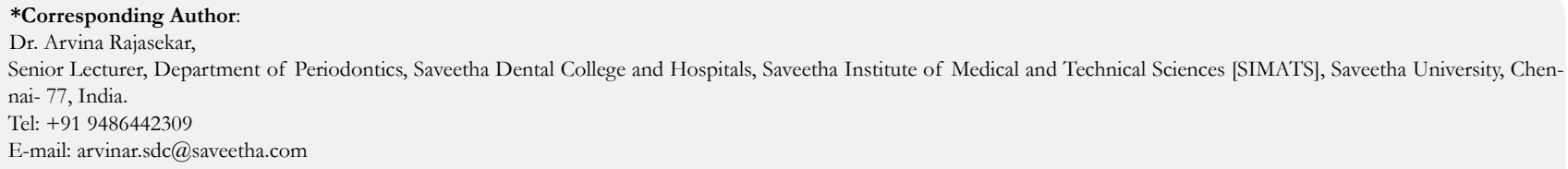

Citation: Allour Vaishnavi, Arvina Rajasekar. Effect Of Calcium Supplementation As An Adjunct To Scaling And Root Planing In The Treatment Of Chronic Periodontitis. Int J Dentistry Oral Sci. 2021;8(9):4588-4592. doi: http://dx.doi.org/10.19070/2377-8075-21000934

Copyright: Dr. Arvina Rajasekar ${ }^{\circ}$ 2021. This is an open-access article distributed under the terms of the Creative Commons Attribution License, which permits unrestricted use, distribution and reproduction in any medium, provided the original author and source are credited. 
Calcium is thought to be potentially influencing risk of periodontal disease through three mechanisms: maintenance of oral bone health, anti-inflammatory activity and antimicrobial activity [17]. Vitamin D is essential for consumption of calcium from the gut and re-absorption of calcium from kidneys and bone formation in order to maintain adequate plasma calcium concentrations for calcium homeostasis, bone mineralisation and immunity [18]. There is biologic surmise that multiple actions of calcium are potentially appealing for the management of chronic periodontitis, whose pathogenesis is based on bacterial driven inflammation[19, 20]. It is speculated that the status of calcium could modify the risk of periodontitis by preventing alveolar bone loss or by mediation of the host's immune response to infection [21, 22]. Thus, there is evidence pointing to the potential role of calcium intake on dental health; however, there are controversies regarding the role of calcium supplementation in chronic periodontitis and its management $[23,24]$. Definition regarding the use of optimum levels of calcium for maintenance of bone health has been a matter of debate [25-27].

Our team has extensive knowledge and research experience that has translate into high quality publications [28-47]. Literature evidence reveals only minimal studies have assessed the management of chronic periodontitis with calcium supplementation[48-53] Therefore, the aim of this article was to assess the effect of calcium supplementation as an adjunct to scaling and root planing in the management of chronic periodontitis among the patients reported to Saveetha Dental College and Hospitals, Chennai.

\section{Materials and Methods}

\section{Study Population:}

The present randomized clinical trial was carried out from June 2020 to December 2020 in the Department of Periodontics, Saveetha Dental College and Hospitals, Chennai, India. A total of 22 patients with generalised chronic periodontitis were enrolled. The ethical clearance was obtained from the Institutional Ethical Committee and a written informed consent was obtained from all the study participants.

\section{Inclusion Criteria:}

Patients who were systemically healthy, presence of at least 20 teeth, probing depth of 4-5 $\mathrm{mm}$, presence of bleeding on probing (BOP) in at least $30 \%$ of the sites were included in the study.

\section{Exclusion Criteria:}

Smokers, pregnant or lactating mothers, patients under long term medications, systemically compromised patients were excluded from the study.

\section{Study Design:}

The sample size was taken to be 22, with 11 participants in each group Group 1, [Scaling and root planing plus placebo], Group 2, [Scaling and root planing plus calcium supplementation]. Participants were assigned to the groups by a person not involved in the study. All the subjects were assigned into group 1 and group 2 via the simple lottery method. The participants in group 1 were asked to take the placebo for three weeks and group 2 were instructed to take the Calcium supplementation for three weeks.

\section{Clinical Parameters:}

- Loe and Silness Gingival Index (GI)

- $\quad$ Pocket Depth

Before recording the clinical parameters, thorough scaling and root planing was done using ultrasonic scalers. Both the parameters were then recorded (baseline). Then the respective groups were asked to intake placebo and Calcium supplements (500mg/ day) for 3 weeks and the same index and pocket depth was recorded post 3 weeks.

\section{Statistical Analysis:}

The data was analyzed using Statistical Package for Social Sciences (SPSS Software, Version 23.0). Descriptive and inferential statistics were done for data summarization and presentation. Unpaired t-test was used to compare the mean values of pocket depth and gingival index between the groups. The analysed data were interpreted as graphs and tabulations.

\section{Results}

In the present study 22 periodontitis patients were enrolled. 11 patients were enrolled in group 1 (scaling and root planing), while the remaining 11 patients were enrolled in group 2 (scaling, root planing and Calcium supplements). The study was carried out as a randomized clinical trial. The pocket depth and gingival index of both the groups were compared at baseline and after 3 weeks.

It was observed that there was a significant reduction in the pocket depth and gingival index scores of both the groups post 3 weeks. The group in which only scaling and root planing was done was found to have a mean gingival index value of $2.89 \pm 0.02$ at baseline and $2.20 \pm 0.01$ after 3 weeks. The gingival index was measured to be $2.92 \pm 0.03$ at baseline in the group which took Calcium supplements in adjunct to scaling and root planing and post 3 weeks the gingival index value reported to be $1.50 \pm 0.03$. The difference in gingival index scores between both the groups was found to be statistically significant $(p=0.002)$. [Fig.1, Table.1].

The mean pocket depth of the individuals who underwent only scaling and root planing were found to have a score of $5 \pm 0.05$ at baseline and $3 \pm 0.01$ post 3 weeks. However in the group which used the Calcium supplements as adjunct to scaling and root planing the pocket depth was measured to be $4 \pm 0.02$ at baseline and $2 \pm 0.03$ post 3 weeks. The difference in pocket depth between both the groups was statistically significant, $(p=0.000)$. [Fig.2, Table.1].

\section{Discussion}

The present study assessed the effect of calcium supplementation as an adjunct to scaling and root planing in the treatment of chronic periodontitis.

In the present study, all the clinical parameters assessed in both groups showed that both interventions were effective in restoring periodontal health. 
Table 1. Comparison of mean gingival index score and pocket depth between the study groups using unpaired t-test.

\begin{tabular}{|c|c|c|c|c|c|c|c|c|c|c|}
\hline & & \multicolumn{2}{|c|}{$\begin{array}{l}\text { Levene's test for equali- } \\
\text { ty of variances }\end{array}$} & \multicolumn{7}{|c|}{ t-test for equality of means } \\
\hline & & \multirow[t]{2}{*}{ F } & \multirow[t]{2}{*}{ Sig. } & \multirow[t]{2}{*}{$\mathrm{t}$} & \multirow[t]{2}{*}{ df } & \multirow[t]{2}{*}{$\begin{array}{c}\text { Sig. } \\
\text { (2-tailed) }\end{array}$} & \multirow[t]{2}{*}{$\begin{array}{l}\text { Mean differ- } \\
\text { ence }\end{array}$} & \multirow[t]{2}{*}{$\begin{array}{l}\text { Std. error } \\
\text { difference }\end{array}$} & \multicolumn{2}{|c|}{$\begin{array}{l}95 \% \text { confidence interval of } \\
\text { the difference }\end{array}$} \\
\hline & & & & & & & & & lower & upper \\
\hline $\begin{array}{l}\text { GINGIVAL } \\
\text { INDEX }\end{array}$ & $\begin{array}{l}\text { Equal variances } \\
\text { assumed } \\
\text { Equal variances } \\
\text { not assumed }\end{array}$ & 11.075 & 0.002 & $\begin{array}{l}1.669 \\
1.669\end{array}$ & $\begin{array}{c}42 \\
35.127\end{array}$ & $\begin{array}{l}0.103 \\
0.104\end{array}$ & $\begin{array}{l}0.336 \\
0.336\end{array}$ & $\begin{array}{l}0.201 \\
0.201\end{array}$ & $\begin{array}{c}0.07 \\
0.072\end{array}$ & $\begin{array}{l}0.743 \\
0.745\end{array}$ \\
\hline $\begin{array}{l}\text { POCKET } \\
\text { DEPTH }\end{array}$ & $\begin{array}{l}\text { Equal variances } \\
\text { assumed } \\
\text { Equal variances } \\
\text { not assumed }\end{array}$ & 24.518 & 0 & $\begin{array}{l}2.689 \\
2.689\end{array}$ & $\begin{array}{c}42 \\
31.03\end{array}$ & $\begin{array}{c}0.01 \\
0.011\end{array}$ & $\begin{array}{l}1 \\
1\end{array}$ & $\begin{array}{l}0.372 \\
0.372\end{array}$ & $\begin{array}{l}0.249 \\
0.241\end{array}$ & $\begin{array}{l}1.751 \\
1.759\end{array}$ \\
\hline
\end{tabular}

Figure 1. Comparison of difference between scaling and root planing alone versus scaling and root planing with Calcium supplementation in terms of gingival index scores. $\mathrm{X}$-axis depicts the modality of treatment adopted in the study: scaling and root planing, scaling root planing with calcium supplement. The Y-axis depicts the mean gingival index value. Blue bar depicts the preoperative gingival index scores; green bar depicts the postoperative gingival index scores. The reduction in gingival index score was higher in the group which had taken Calcium supplements as adjunct compared to the group in which only scaling and root planing was done. The difference was found to be statistically significant with the $p$ value of 0.002 (unpaired t-test).

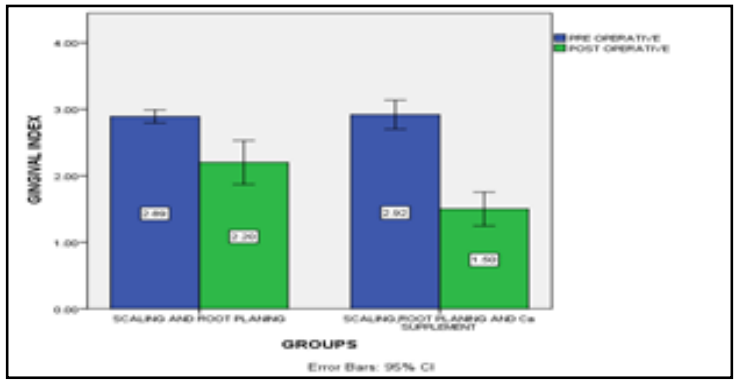

Figure 2. Comparison of difference between scaling and root planing alone versus scaling and root planing with Calcium supplementation in terms of pocket depth. X-axis depicts the modality of treatment adopted in the study: scaling and root planing, scaling root planing with calcium supplement. The Y-axis depicts the mean pocket depth. Blue bar depicts the preoperative pocket depth measured, green bar depicts the postoperative pocket depth measured. The reduction in pocket depth in the group which had taken calcium supplements as adjunct was higher to that compared to the group in which only scaling and root planing was done. The difference was found to be statistically significant with the $p$ value of 0.000 (unpaired t-test).

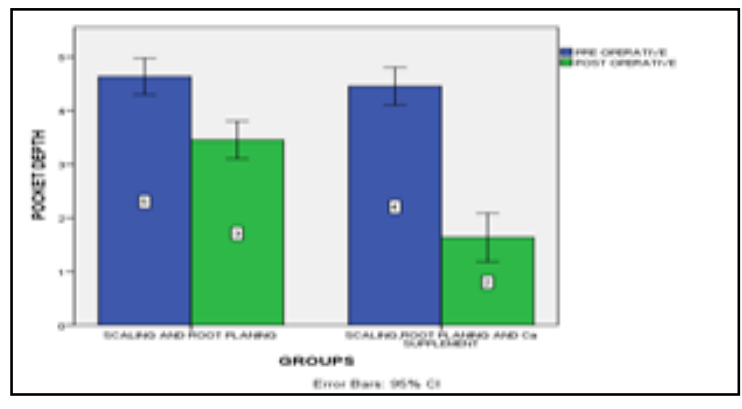

However, when compared with patients who received scaling and root planing alone, patients who received calcium supplementation along with scaling and root planing showed drastic improvement in terms of probing pocket depth and gingival index.

Garcia et al.,[48]conducted a study to assess the effects of vitamin $\mathrm{D}$ and calcium supplementation on chronic periodontitis. In that study, it was observed calcium and vitamin $\mathrm{D}$ have positive effects on periodontal health. Similar results were obtained in the present study. But the difference is that in the previous study, higher doses of calcium supplementation were given for a longer time period.
The study of Hiremath et al.,[49] evaluated the anti-inflammatory effect of calcium on gingivitis at various doses which revealed that there was a dose-dependent anti-inflammatory effect of calcium on gingivitis and concluded that calcium was a safe and effective anti-inflammatory agent in doses $500 \mathrm{mg}$. But in their study, clinical parameters like gingival index, oral hygiene index simplified, plaque index were considered. But in this study, we have included subjects with generalized chronic periodontitis and analysed the effect of calcium on gingival and periodontal parameters. However, improvement in gingival health was similar to the previous study. 
Milley et al.,[50] conducted a cross-sectional study and assessed the influence of vitamin $\mathrm{D}$ and calcium supplementation on chronic periodontitis and observed that there was better periodontal health after taking calcium and vitamin $\mathrm{D}$ supplementation. In their study, clinical parameters like probing depth, bleeding on probing, gingival index, furcation involvement, attachment loss and alveolar crest height were considered. But in the present study, gingival index and probing pocket depth alone were taken and proved that calcium supplementation gives a better periodontal health.

Keiko Tanaka et al.,[51] investigated the relationship between calcium intake and the prevalence of periodontal disease and concluded that higher calcium intake may be inversely associated with the prevalence of periodontal disease. Hildebolt et al., [52] studied the effect of vitamin D and/or calcium supplementation on periodontitis and concluded that calcium supplementation and vitamin $\mathrm{D}$ have a beneficial effect on clinical parameters of periodontitis as a complementary therapy. The results of the present study were in agreement with the previous studies.

Even though we found that calcium supplementation along with scaling and root planing significantly reduces the clinical parameters like gingival index and probing pocket depth, when compared to scaling to root planing alone, these results cannot be generalised since this study was conducted among a small population with short term follow-up. Therefore, more randomized controlled clinical trials with long term follow-up are warranted to confirm this finding.

\section{Conclusion}

The present study reveals that the calcium supplementation given as an adjunct to scaling and root planing was more effective compared to scaling and root planing alone in the management of chronic periodontitis.

\section{Acknowledgement}

The authors would like to acknowledge the help rendered by Saveetha Dental College and Hospitals, Saveetha Institute of Medical and Technical Sciences, Saveetha University, Chennai.

\section{Funding}

The present project is funded by

- Saveetha Institute of Medical and Technical Sciences

- Saveetha Dental College and Hospitals

- Saveetha University

- RK Tax Consultancy, Andhra Pradesh.

\section{References}

[1]. S TA, Thanish AS, Rajasekar A, Mathew MG. Assessment of tooth loss in chronic periodontitis patients with and without diabetes mellitus: A crosssectional study. Int. j. res. pharm. sci. 2020;11: 1927-31.

[2]. Rajeshwaran N, Rajasekar A, Kaarthikeyan G. Prevalence of Pathologic Migration in Patients with Periodontitis: A Retrospective Analysis. J. Complement. Med. Res. 2020;11(4):172-8.

[3]. Rajeshwaran N, Rajasekar A. Prevalence of Angular Bone Defects in Chronic Periodontitis Patients with and without Systemic Diseases. Indian J. Forensic
Med. Toxicol. 2020 Oct 1;14(4).

[4]. B G, Geethika B, Rajasekar A, Chaudary M. Comparison of periodontal status among pregnant and non-pregnant women. Int. j. res. pharm. sci. 2020;11:1923-6.

[5]. Rajasekar A, Lecturer S, Department of Periodontics, Saveetha Dental College and Hospitals, Saveetha Institute of Medical and Technical Sciences, Saveetha University, et al. Assessment Of Periodontal Status among Post Menopausal Women: A Retrospective Study. Int. J. Dent. Oral Sci. 2020: 1063-6.

[6]. Sabarathinam J, Rajasekar A, Madhulaxmi M. Prevalence of Furcation Involvement Among Patients with Periodontitis: A Cross Sectional Study. Int. j. res. pharm. sci. 2020;11: 1483-7.

[7]. Kandhan TS, Rajasekar A. Prevalence of Periodontal Diseases Among Patients with And Without Systemic Diseases-A Retrospective Study. J. Complement. Med. Res. 2020;11(4):155-62.

[8]. SHAH P, RAJASEKAR A, CHAUDHARY M. Assessment of Gender Based Difference in Occurrence of Periodontal Diseases: A Retrospective Study. J. contemp. issues bus. gov. $2021 \mathrm{Feb}$ 16;27(2):521-6.

[9]. SHUKRI N, MOHAMED M, SEKAR AR, SUBRAMANIAM AB. Assessment of periodontal health among patients with diabetes mellitus: a retrospective study. J. contemp. issues bus. gov. 2020 Dec 11;26(2):28-34.

[10]. RAJASEKAR A, CHAUDARY M. Prevalence of Periodontal Diseases Among Individuals Above 45 Years: A Retrospective Study. J. contemp. issues bus. gov. $2021 \mathrm{Feb}$ 19;27(2):527-33.

[11]. C C, Cinthura C, Nasim I, Rajasekar A. Association Between Type of Tooth and Number of Walls Present in Teeth Undergoing FRC Post - An Institution Based Retrospective Study. Int. j. res. pharm. sci. 2020;11: 123-8.

[12]. Dabholkar CS, Shah M, Kathariya R, Bajaj M, Doshi Y. Comparative Evaluation of Antimicrobial Activity of Pomegranate-Containing Mouthwash Against Oral-Biofilm Forming Organisms: An Invitro Microbial Study. J Clin Diagn Res. 2016 Mar;10(3):ZC65-9.Pubmed PMID: 27135005.

[13]. Garmasheva I, Kovalenko N, Voychuk S, Ostapchuk A, Livins'ka O, Oleschenko L. Lactobacillus species mediated synthesis of silver nanoparticles and their antibacterial activity against opportunistic pathogens in vitro. Bioimpacts. 2016;6(4):219-223.Pubmed PMID: 28265538.

[14]. Mohapatra S, Leelavathi L, Meignana AI, Pradeep KR, Rajeshkumar S. Assessment of Antimicrobial Efficacy of Zinc Oxide Nanoparticles Synthesized Using Clove and Cinnamon Formulation against Oral Pathogens--An In Vitro Study. J. Evol. Med. Dent. Sci. 2020 Jul 20;9(29):2034-9.

[15]. Evaluation of Antiplaque and Antigingivitis Effects of A Herbal Mouthwash. Int. J. Pharm. Res.. 2021;13.

[16]. Chouksey A, Dilliwal H, Agrawal R, Khashu H. Efficacy of Aloe vera Gel delivered locally as an Adjunct to Scaling and Root Planing in the Treatment of Chronic Periodontitis: A Pilot Study. Int J Oral Care. 2017;5: 370-5.

[17]. Millen AE, Hovey KM, LaMonte MJ, Swanson M, Andrews CA, Kluczynski MA, et al. Plasma 25-hydroxyvitamin D concentrations and periodontal disease in postmenopausal women. J Periodontol. 2013 Sep;84(9):1243-56.

[18]. Twardowski SE, Wactawski-Wende J, Hovey KM, Andrews CA, Banack HR, LaMonte MJ, et al. Plasma 25-Hydroxyvitamin D Concentrations and Serum and Salivary C-Reactive Protein in the Osteoporosis and Periodontal Disease Study. Nutrients. 2021 Mar 31;13(4):1148.Pubmed PMID: 33807159.

[19]. Paul TV, Thomas N, Seshadri MS, Oommen R, Jose A, Mahendri NV. Prevalence of osteoporosis in ambulatory postmenopausal women from a semiurban region in Southern India: relationship to calcium nutrition and vitamin D status. Endocr Pract. 2008 Sep;14(6):665-71.Pubmed PMID: 18996783.

[20]. Perayil J, Menon KS, Kurup S, Thomas AE, Fenol A, Vyloppillil R, et al. Influence of vitamin $\mathrm{D} \&$ calcium supplementation in the management of periodontitis. J Clin Diagn Res. 2015 Jun;9(6):ZC35-8.

[21]. Herrmann U, Schwille PO, Schmiedl A, Fan J, Manoharan M. Acute effects of calcium sodium citrate supplementation of a test meal on mineral homeostasis, oxalate, and calcium oxalate crystallization in the urine of healthy humans--preliminary results in patients with idiopathic calcium urolithiasis. Biomed Pharmacother. 1999 Jun;53(5-6):264-73.Pubmed PMID: 10424248.

[22]. Zare Javid A, Hormoznejad R, Yousefimanesh HA, Zakerkish M, HaghighiZadeh MH, Dehghan P, et al. The Impact of Resveratrol Supplementation on Blood Glucose, Insulin, Insulin Resistance, Triglyceride, and Periodontal Markers in Type 2 Diabetic Patients with Chronic Periodontitis. Phytother Res. 2017 Jan;31(1):108-114.Pubmed PMID: 27807887.

[23]. Bristow S. Effects of Calcium on Indices of Bone and Cardiovascular Health, and on Cancer .2014:374.

[24]. Ross AC, Taylor CL, Yaktine AL, Del Valle HB. Committee to Review Dietary Reference Intakes for Vitamin D and Calcium. Dietary reference intakes for calcium and vitamin D. IOM. 2011: 1132.

[25]. Perayil J, Menon KS, Kurup S, Thomas AE, Fenol A, Vyloppillil R, et al. Influence of vitamin D \& calcium supplementation in the management of 
periodontitis. J. Clin. Diagnostic Res. 2015 Jun;9(6):ZC35.

[26]. Weaver CM, Heaney RP. Calcium in Human Health. SSBM. 2007: 472. Available from:

[27]. Sampath V. The effects of calcium supplementation on adipocyte metabolism in overweight women. UC Davis. 2004:390.

[28]. Ramesh A, Varghese S, Jayakumar ND, Malaiappan S. Comparative estimation of sulfiredoxin levels between chronic periodontitis and healthy patients - A case-control study. J Periodontol. 2018 Oct;89(10):1241-1248.Pubmed PMID: 30044495

[29]. Paramasivam A, Priyadharsini JV, Raghunandhakumar S, Elumalai P. A novel COVID-19 and its effects on cardiovascular disease. Hypertens. Res. $2020 \mathrm{Jul} ; 43(7): 729-30$.

[30]. S G, T G, K V, Faleh A A, Sukumaran A, P N S. Development of 3D scaffolds using nanochitosan/silk-fibroin/hyaluronic acid biomaterials for tissue engineering applications. Int J Biol Macromol. 2018 Dec;120(Pt A):876885.Pubmed PMID: 30171951.

[31]. Del Fabbro M, Karanxha L, Panda S, Bucchi C, Doraiswamy JN, Sankari $\mathrm{M}$, et al. Autologous platelet concentrates for treating periodontal infrabony defects. Cochrane Database Syst. Rev. 2018;11: CD011423.

[32]. Paramasivam A, Vijayashree Priyadharsini J. MitomiRs: new emerging microRNAs in mitochondrial dysfunction and cardiovascular disease. Hypertens Res. 2020 Aug;43(8):851-853.Pubmed PMID: 32152483.

[33]. Jayaseelan VP, Arumugam P. Dissecting the theranostic potential of exosomes in autoimmune disorders. Cell Mol Immunol. 2019 Dec;16(12):935-936. Pubmed PMID: 31619771.

[34]. Vellappally S, Al Kheraif AA, Divakar DD, Basavarajappa S, Anil S, Fouad $\mathrm{H}$. Tooth implant prosthesis using ultra low power and low cost crystalline carbon bio-tooth sensor with hybridized data acquisition algorithm. Comput Commun. 2019 Dec 15;148:176-84.

[35]. Vellappally S, Al Kheraif AA, Anil S, Assery MK, Kumar KA, Divakar DD. Analyzing Relationship between Patient and Doctor in Public Dental Health using Particle Memetic Multivariable Logistic Regression Analysis Approach (MLRA2). J Med Syst. 2018 Aug 29;42(10):183.Pubmed PMID: 30155746.

[36]. Varghese SS, Ramesh A, Veeraiyan DN. Blended Module-Based Teaching in Biostatistics and Research Methodology: A Retrospective Study with Postgraduate Dental Students. J Dent Educ. 2019 Apr;83(4):445-450.Pubmed PMID: 30745352

[37]. Venkatesan J, Singh SK, Anil S, Kim SK, Shim MS. Preparation, Characterization and Biological Applications of Biosynthesized Silver Nanoparticles with Chitosan-Fucoidan Coating. Molecules. 2018 Jun 12;23(6):1429.Pubmed PMID: 29895803.

[38]. Alsubait SA, Al Ajlan R, Mitwalli H, Aburaisi N, Mahmood A, Muthurangan $\mathrm{M}$, et al. Cytotoxicity of different concentrations of three root canal sealers on human mesenchymal stem cells. Biomolecules. 2018 Sep;8(3):68.

[39]. Venkatesan J, Rekha PD, Anil S, Bhatnagar I, Sudha PN, Dechsakulwatana C, et al. Hydroxyapatite from cuttlefish bone: isolation, characterizations, and applications. Biotechnol Bioprocess Eng. 2018 Aug;23(4):383-93.

[40]. Vellappally S, Al Kheraif AA, Anil S, Wahba AA. IoT medical tooth mount- ed sensor for monitoring teeth and food level using bacterial optimization along with adaptive deep learning neural network. Measurement. 2019 Mar 1;135:672-7.

[41]. PradeepKumar AR, Shemesh H, Nivedhitha MS, Hashir MMJ, Arockiam $S$, Uma Maheswari TN, et al. Diagnosis of Vertical Root Fractures by Conebeam Computed Tomography in Root-filled Teeth with Confirmation by Direct Visualization: A Systematic Review and Meta-Analysis. J Endod. 2021 Aug;47(8):1198-1214.Pubmed PMID: 33984375.

[42]. R H, Ramani P, Tilakaratne WM, Sukumaran G, Ramasubramanian A, Krishnan RP. Critical appraisal of different triggering pathways for the pathobiology of pemphigus vulgaris-A review. Oral Dis. 2021 Jun 21.Pubmed PMID: 34152662.

[43]. Ezhilarasan D, Lakshmi T, Subha M, Deepak Nallasamy V, Raghunandhakumar S. The ambiguous role of sirtuins in head and neck squamous cell carcinoma. Oral Dis. 2021 Feb 11.Pubmed PMID: 33570800.

[44]. Sarode SC, Gondivkar S, Sarode GS, Gadbail A, Yuwanati M. Hybrid oral potentially malignant disorder: A neglected fact in oral submucous fibrosis. Oral Oncol. 2021 Oct;121:105390.Pubmed PMID: 34147361.

[45]. Kavarthapu A, Gurumoorthy K. Linking chronic periodontitis and oral cancer: A review. Oral Oncol. 2021 Jun 16:105375.

[46]. Vellappally S, Al-Kheraif AA, Anil S, Basavarajappa S, Hassanein AS. Maintaining patient oral health by using a xeno-genetic spiking neural network. J Ambient Intell Humaniz Comput. 2018 Dec 14:1-9.

[47]. Aldhuwayhi S, Mallineni SK, Sakhamuri S, Thakare AA, Mallineni S, Sajja R, et al. Covid-19 Knowledge and Perceptions Among Dental Specialists: A Cross-Sectional Online Questionnaire Survey. Risk Manag Healthc Policy. 2021 Jul 7;14:2851-2861.Pubmed PMID: 34262372.

[48]. Garcia MN, Hildebolt CF, Miley DD, Dixon DA, Couture RA, Spearie $\mathrm{CL}$, et al. One-year effects of vitamin $\mathrm{D}$ and calcium supplementation on chronic periodontitis. J Periodontol. 2011 Jan;82(1):25-32.Pubmed PMID: 20809866.

[49]. Hiremath V, Rao C, Naiak V, Prasad KV. Anti-inflammatory effect of vitamin D on gingivitis: a dose response randomised controlled trial. Indian J. Public Health. 2013;57(1):29-32.

[50]. Miley DD, Garcia MN, Hildebolt CF, Shannon WD, Couture RA, Anderson Spearie CL, et al. Cross-sectional study of vitamin D and calcium supplementation effects on chronic periodontitis. J Periodontol. 2009 Sep;80(9):1433-9.Pubmed PMID: 19722793.

[51]. Tanaka K, Miyake Y, Okubo H, Hanioka T, Sasaki S, Miyatake N, et al. Calcium intake is associated with decreased prevalence of periodontal disease in young Japanese women. Nutr J. 2014 Nov 24;13:109.Pubmed PMID: 25421835.

[52]. Hildebolt CF. Effect of vitamin D and calcium on periodontitis. J. Periodontol. 2005 Sep;76(9):1576-87.

[53]. Rajasekar A, Mathew MG. Prevalence of Periodontal Disease among Individuals between 18-30 Years of Age: A Retrospective Study. Ann Med Health Sci Res. 2021 Jun 30. 